\title{
Is Severity of Liver Enzyme Derangement Related to Severity of Hypertension in Patients with Preeclampsia?
}

\author{
Puneeta M, Gupta V, Chawla D and Aarushi C* \\ Baba Saheb Ambedkar Medical College and Hospital, India
}

*Corresponding author: Chaudhary Aarushi, Dr. Baba Saheb Ambedkar Medical College and Hospital, Rohini, New Delhi, India, Email: prof.aarushi@gmail.com

\section{Research Article}

Volume 1 Issue 4

Received Date: October 27, 2016

Published Date: November 30, 2016
Objective: To evaluate the severity of liver enzyme derangement and correlate it with severity of hypertension in preeclampsia patients.

Keywords: Gamma glutamyl transpeptidase(GGTP); Placental abruption; Hepatic Encephalopathy; Serum bile acid

\section{Introduction}

During pregnancy, virtually every organ system undergoes anatomical and functional changes in response to increased demands of rapidly growing fetus and placenta. There are intense anatomical and physiological changes in almost all body systems, most importantly haematological, cardiovascular, respiratory, gastrointestinal \& biliary etc. These changes are evident in the form of altered biochemical markers. There is no significant increase in liver size during pregnancy. Alterations in the liver function tests are also minimal. The amino transverses (AST and ALT), gamma glutamyl transpeptidase(GGTP), total bilirubin, and serum bile acid level remain almost same as non pregnant value[1]. There is evidence to prove that severity of liver function test derangement is directly related to severity of preeclampsia which in turn is related to severity of maternal complications in preeclamptic women [2,3]. These complications can be noted in the form of Severity of Preeclampsia, Impending eclampsia, Eclampsia, HELLP syndrome, Partial HELLP syndrome, Placental abruption, ICU stay, Liver failure, Renal failure, Hepatic Encephalopathy, Post Partum haemorrhage, PRES syndrome.

\section{Methods}

A Prospective Analytical Observational study being carried out at Dr. Baba Saheb Ambedkar Medical College \& Hospital, Delhi which is a 500 bedded hospital of Delhi Govt. Study period was from July 2016 to September 2016. Informed consent was obtained .50 preeclamptic patients with period of gestation $>24$ weeks meeting inclusion and exclusion criteria were enrolled. Liver function tests were done fortnightly for all .Those with AST $>25 \mathrm{IU} / \mathrm{L}, \mathrm{ALT}>32 \mathrm{IU} / \mathrm{L}, \mathrm{ALP}>418$ IU/L were called weekly. On every visit complete history, physical examination done and BLOOD PRESSURE noted. Patients managed, classified, terminated as per RCOG Guideline. This study is a part of a going two year old study for development of a cut off value of LFTs for management of preeclampsia.

\section{Statistical analysis}

Pearson Correlation coefficient / Spears man correlation coefficient (for non parametric data) was used to find out correlation between severity of hypertension and severity of liver enzyme derangement.

\begin{tabular}{|c|c|c|c|}
\hline & ALT IU/L & AST IU/L \\
\hline $\begin{array}{c}\text { Systolic } \\
\text { BP }\end{array}$ & $\begin{array}{c}\text { Correlation } \\
\text { coefficient }\end{array}$ & 0.322 & 0.121 \\
\hline $\begin{array}{c}\text { Piastolic } \\
\text { BP }\end{array}$ & $\begin{array}{c}\text { Correluation } \\
\text { coefficient }\end{array}$ & 0.28 & 0.69 \\
\hline & P value & 0.98 & 0.343 \\
\hline & N value & 13 & 13 \\
\hline
\end{tabular}

Table 1: Correlation Table. 


\section{Results}

Out of 50 patients with Preeclampsia, 13 (25\%) had deranged liver enzymes. Out of these 13, 4 developed eclampsia, 5 developed abruption, one HELLP syndrome, one case noted for DIC, one case with pulmonary edema, one maternal death noted. AST, ALT were noted to be around 70IU/L in patients with complications. BP noted to $b e>/=150 / 100$ in all patients with deranged enzymes.

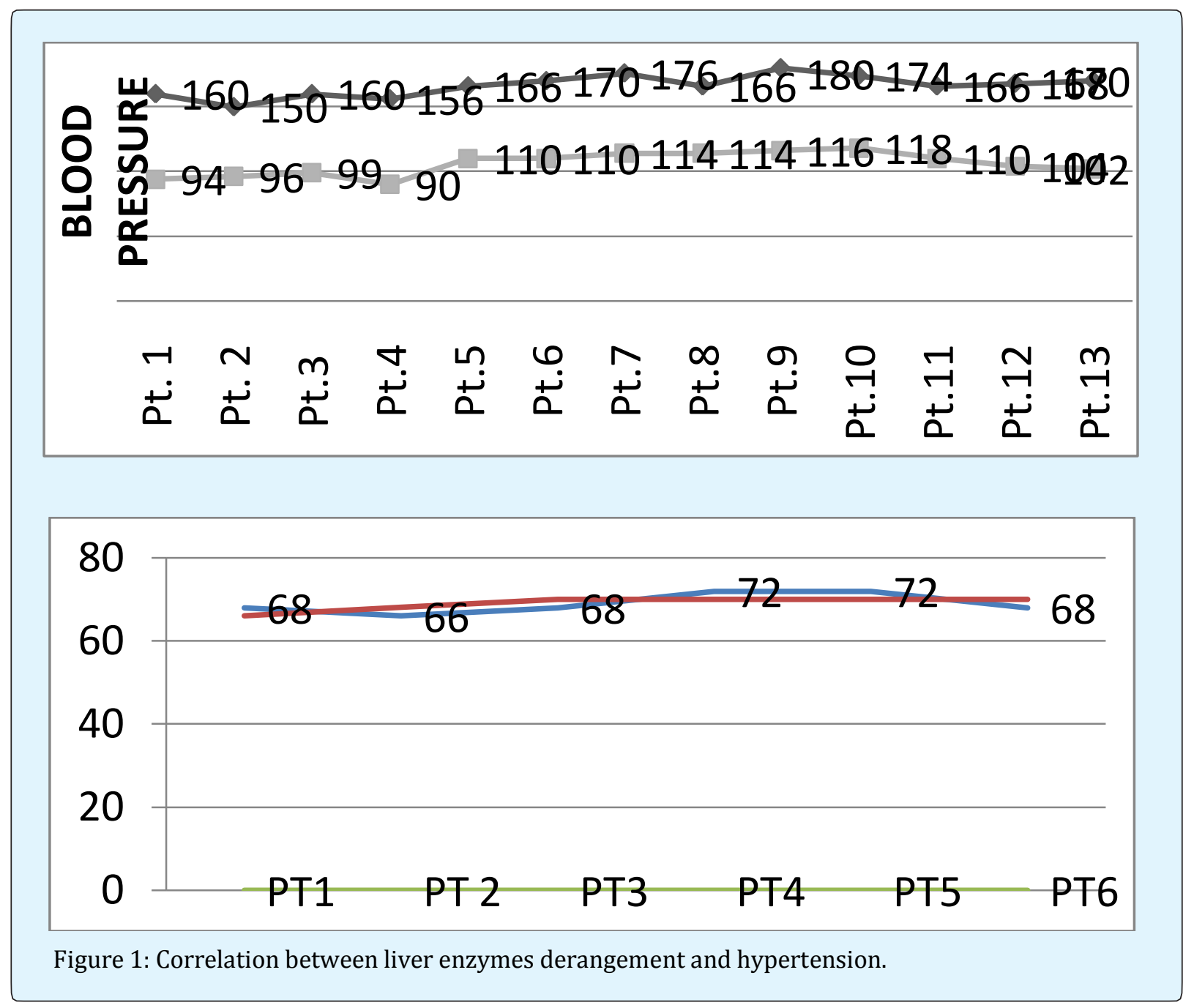

\section{Conclusions}

Severity of liver enzymes derangement is directly correlated with severity of hypertension which in turn is directly correlated with adverse maternal outcome. Statistics are not correlated at this stage since sample size is small, further studies need to be done with increased sample size.

\section{References}

1. Combes B, Adams RH (1971) Disorder of the liver in pregnancy: Pathophysiology of gestation.

2. Loi K, Khoo CK, Jan KH, Yeo GS, Kwek K (2007) A reveiew of 93 cases of severe preeclampsia in Singapore: are there risk factors for complications? Singapore Med J 48(9): 808-812. 
3. Thangaratinam S, Koopmans CM, Zamora Javier, Ismail KM (2011) Accuracy of liver function tests for predicting adverse maternal and fetal outcomes in women with preeclampsia:a systematic review. Acta Obstet Gynecol Scand 90(6): 574-584. 